
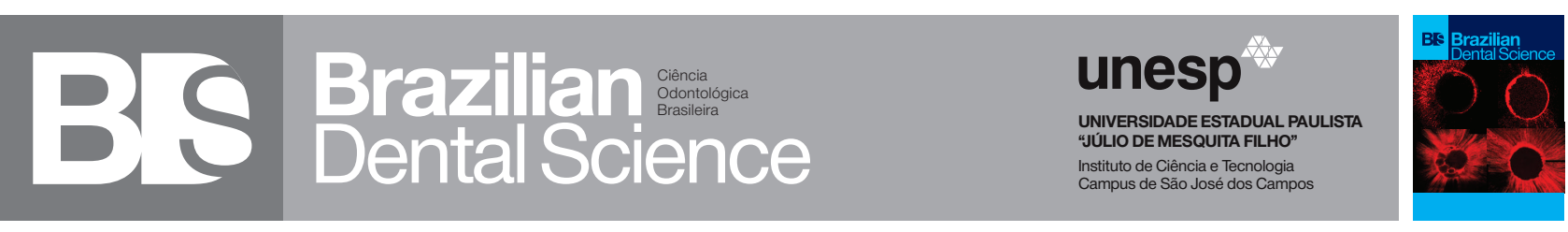

\title{
Effect of glass-fiber post on the biomechanical behavior of teeth with direct veneers
}

\author{
Efeito do pino de fibra de vidro no comportamento biomecânico de dentes com facetas diretas
}

\begin{abstract}
Ana Luiza Barbosa JUREMA', Marcela Moreira PENTEADO², João Paulo Mandes TRIBST2 ${ }^{2}$, Taciana Marco Ferraz CANEPPELE${ }^{1}$, Alexandre Luiz Souto BORGES ${ }^{2}$

1 - São Paulo State University (UNESP) - Institute Science and Technology, São José dos Campos - Departament of Restorative Dentistry - São José dos Campos - SP - Brazil.

2 - São Paulo State University (UNESP) - Institute Science and Technology, São José dos Campos - Departament of Dental Materials and Prosthodontics - São José dos Campos - SP - Brazil.
\end{abstract}

\section{ABSTRACT}

Objective: This study aimed to evaluate the biomechanical behaviour of endodontically treated teeth with direct veneer that received or not intra-radicular glass fiber post by finite elements analysis. Material and methods: Six models were designed, varying the presence or absence of glass fiber post and the thickness of direct veneer $(0.5,0.7$ and $1 \mathrm{~mm})$. Tridimensional models of maxillary central incisors were obtained with CAD software, Rhinoceros 4.0, and transferred to CAE software, ANSYS 17.2 , which a $100 \mathrm{~N}$ load was applied in a $45^{\circ}$ on the lingual surface to simulate functional movements. Geometry contacts were bonded, and the structures were isotropic, linear, elastics, and homogeneous. After coherence and convergence analysis of mashes, the chosen fail criterion was the maximum principal stresses. Results: For cement, glass fiber post, the stress distribution was similar independently of glass fiber post presence or veneer thickness. Models with glass fiber post had better stress distribution and lower values of maximum stress for inner dentin and veneers. Veneers with 0.5 and $1 \mathrm{~mm}$ had higher stress concentration areas. Conclusions: It can be concluded that glass fiber post is favorable for restored teeth with direct veneers, and very thin or very thick preparations can damage the biomechanical behavior of restorations.

\section{KEYWORDS}

Dental Veneers; Finite Element Analysis; Nonvital Tooth; Post and Core Technique.

\section{RESUMO}

Objetivo: Este estudo teve como objetivo avaliar o comportamento biomecânico de dentes tratados endodonticamente com faceta direta que receberam ou não pinos de fibra de vidro intrarradicular através de análise de elementos finitos. Material e métodos: Foram desenhados seis modelos, variando a presença ou ausência do pino de fibra de vidro e a espessura da faceta direta (0,5, 0,7 e $1 \mathrm{~mm})$. Modelos tridimensionais de incisivos centrais superiores foram obtidos com o software CAD, Rhinoceros 4.0, e transferidos para o software CAE, ANSYS 17.2, cuja carga de $100 \mathrm{~N}$ foi aplicada a $45^{\circ}$ na superfície lingual para simular movimentos funcionais. Os contatos geométricos foram colados e as estruturas eram isotrópicas, lineares, elásticas e homogêneas. Após análise de coerência e convergência de malhas, o critério de falha escolhido foi a tensão principal máxima. Resultados: Para cimento e pino de fibra de vidro, a distribuição de tensões foi semelhante independentemente da presença do pino de fibra de vidro ou da espessura da faceta. Os modelos com pinos de fibra de vidro apresentaram melhor distribuição de tensão e menores valores de tensão máxima para dentina interna e facetas. Facetas com 0,5 e $1 \mathrm{~mm}$ apresentaram maiores áreas de concentração de estresse. Conclusões: Pode-se concluir que o pino de fibra de vidro é favorável para dentes restaurados com facetas diretas, e preparações muito finas ou muito espessas podem prejudicar o comportamento biomecânico das restaurações.

\section{PALAVRAS-CHAVE}

Facetas dentárias; Análise de elementos finitos; Dente não vital; Técnica de pino e núcleo. 


\section{INTRODUCTION}

$\mathrm{E}_{\mathrm{a}}$ sthetics re-establishment is a treatment with a high demand for patients that suffered any interference in smile harmony in tooth discoloration, change in shape and position, extensive caries, or deficient restorations [1]. Resin composite direct veneer is performed in anterior teeth that have changes involving buccal surface [2]. It is a conservative technique that has some advantages over ceramic veneer or total crowns, such as lower cost, fewer sessions and eases to repair $[2,3]$.

Although the direct veneers procedures are based on conservative technique and focused on the maintenance of tooth structure [4], the preparation of direct veneer can decrease the tooth resistance [5]. It is common to obtain a large preparation for discolored tooth, due to the need of many composite resin layers to cover this unfavorable condition [6].

Many of the teeth that need aesthetical restorations present endodontic treatment and its procedures can cause a decrease of the stiffness due to pulp access [7]. Also, the endodontic treatment promotes the loss of tooth structure through the access cavity and biomechanical preparation [8]. There are differences in mechanical properties between a sound and an endodontically treated anterior tooth when they are analyzed under loading [7]. Furthermore, frequently, the tooth has structure loss due to extensive caries lesions, restorations, or fractures that occurred previously $[9,10]$.

The higher the tooth loss by endodontic and restorative treatment, the weaker it will be, and the fracture risk increases [11]. It is believed that glass-fiber post (GFP) use can reduce coronal and radicular fracture risk, improving tooth properties. The decision to use intra-radicular fiber post depends on the amount of remaining tooth substance. Often, less amount of residual dentin requires additional reinforcement, and it can be achieved by insertion of a fiber post [12]. Despite this, there is not a consensus in the literature related the use or not of GFP for reinforcement of fragile tooth [13-16].
The finite element analysis (FEA) is a tool able to analyze the biomechanical behavior of structures by numerical models. FEA is a nondestructive test, with easy reproduction and can analyze some clinical conditions that hardly can be simulated in vitro $[17,18]$.

This research aimed to evaluate through FEA the influence of glass fiber post and different veneer thickness on biomechanical behavior and stress distribution of endodontically treated maxillary central incisor, restored with resin composite veneers with and without GFP.

\section{MATERIAL AND METHODS}

Six groups were designed for this study. For groups G0.5, G0.7, and G1, there was no GFP, just endodontic treatment and resin composite veneer with three different thickness, $0.5 \mathrm{~mm}, 0.7 \mathrm{~mm}$, and $1.0 \mathrm{~mm}$, respectively. In the other groups (G0.5P, G0.7P, and G1P), GFP was used, and veneers also presented three different thickness $(0.5 \mathrm{~mm}, 0.7 \mathrm{~mm}$, and 1.0 $\mathrm{mm}$, respectively). The group's description is shown in Table I.

Table I - Division of groups.

\begin{tabular}{cccccccc|} 
Groups & $\begin{array}{c}\text { Fiber } \\
\text { post }\end{array}$ & $\begin{array}{c}\text { Thickness } \\
\text { of veneers } \\
(\mathbf{m m})\end{array}$ & $\begin{array}{c}\text { Thickness of remaining } \\
\text { Cervical } \\
\text { dentin(mm) }\end{array}$ & \multicolumn{2}{c|}{ Middle } & Mash metrics \\
third & $\begin{array}{c}\text { Mnird } \\
\text { Incisal }\end{array}$ & $\begin{array}{c}\text { Mash } \\
\text { metrics }\end{array}$ & $\begin{array}{c}\text { Mash } \\
\text { metrics }\end{array}$ \\
\hline G0.5 & No & 0.5 & 2.7 & 2.3 & 1.0 & 125831 & 64127 \\
\hline G0.7 & No & 0.7 & 2.6 & 2.3 & 0.9 & 131201 & 77312 \\
\hline G1 & No & 1.0 & 2.5 & 1.7 & 0.5 & 148075 & 82636 \\
\hline G0.5P & Yes & 0.5 & 2.3 & 1.9 & 0.8 & 129312 & 65411 \\
\hline G0.7P & Yes & 0.7 & 2.1 & 1.9 & 0.6 & 138298 & 78114 \\
\hline G1P & Yes & 1.0 & 2.0 & 1.5 & 0.2 & 151307 & 83267 \\
\hline
\end{tabular}

It was modelled three maxillary central incisors with access and endodontic treatment. The models were divided according to veneer thickness, 0.5, 0.7 and $1 \mathrm{~mm}$. All models were restored with the same resin composite.

Tridimensional model of maxillary central incisor was designed by CAD Rhinoceros (version 4.0SR8; McNeel North America, Seattle, WA) and a previously validated model of endodontically treated maxillary central 
incisor was used [8].

The model was constituted by enamel, dentin, periodontal ligament, medullary bone, cortical bone, resin cement, glass-fiber post, gutta-percha and composite resin (Figure 1).

After modelling, solids were exported in STEP format to computer-aided engineering software (ANSYS 17.2; ANSYS Inc, Houston, TX). Contacts were considered perfectly bonded, and fixture was at the medullar bone base.

Materials properties used in this Ansys software were collected from literature (Table II) and considered isotropic, linearly elastic and homogeneous.

Table II - Material properties: Elastic modulus (E) and Poisson coefficient (v).

\begin{tabular}{|c|c|c|}
\hline Material & $\mathrm{E}(\mathrm{GPa})$ & $\mathbf{v}$ \\
\hline Enamel & $84.00[19]$ & $0.30[19]$ \\
\hline Dentin & $18.00[19]$ & $0.23[19]$ \\
\hline Gutta Percha & $0.14[20]$ & $0.49[20]$ \\
\hline Composite Resin & $14.9[21]$ & 0.30 \\
\hline Glass Fiber Post & $37.00[22]$ & $0.34[22]$ \\
\hline Cement & $10.10[23]$ & 0.30 \\
\hline Periodontal Ligament & $0.00118[24]$ & $0.45[24]$ \\
\hline Cortical Bone & $13.70[25]$ & $0.30[25]$ \\
\hline Medular Bone & $0.00186[26]$ & $0.34[26]$ \\
\hline
\end{tabular}

The models were loaded with $100 \mathrm{~N} / 45 \mathrm{o}$ to the longitudinal axis of the tooth, simulating functional movements (Figure 2) [8]. The results in MPa are presented in graphics. The stress distribution at the interfaces between each structure was analysed by maximum principal stresses or the Von Mises criterion.

\section{RESULTS}

Figure 3 shows the peak of the maximum principal stress of each structure and table III shows these values. It is observed that maximum stress obtained on veneer is indirectly proportional to its thickness and groups of teeth without GFP (G0.5, G0.7, and G1) had the higher values peek of stress. In contrast, groups G0.5P, G0.7P, and G1P presented better stress distribution and lower maximum stress values. In inner dentin, structure can be observed that the higher dentin loss, the higher peak of MPS. In another hand, in enamel, glass fiber post, and cement, the peak of MPS was inversely proportional to veneer thickness. GFP groups presented lower stress loads than groups that did not have GFP. Despite differences among peak of MPS, qualitatively the stress distribution was similar for enamel, glass fiber post and cement.

Table III - Peek of Maximum principal stress (by Mpa) obtained after FEA.

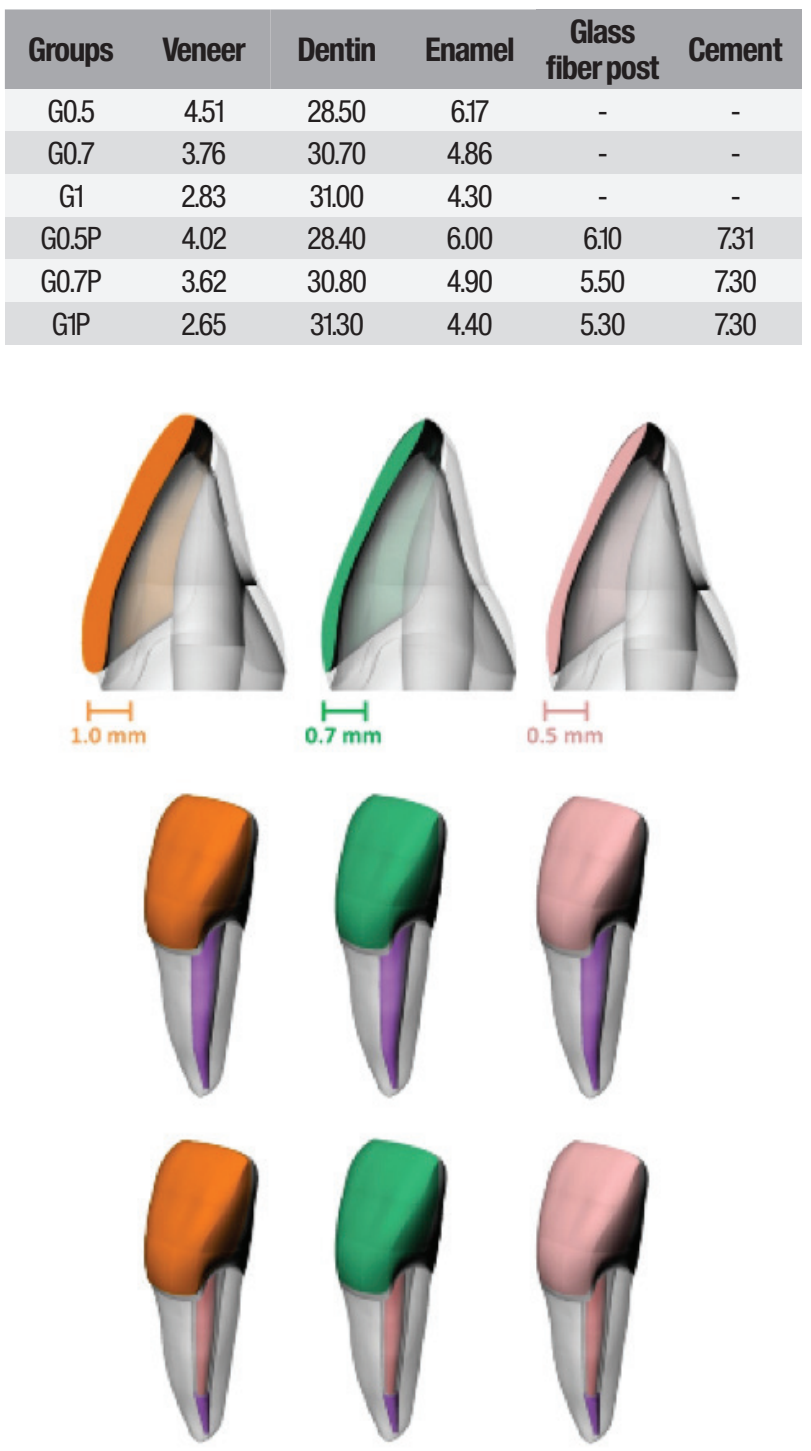

Figure 1 - Schematic illustration of the modeling sequence in Rhinoceros 4.0 CAD Software. 
A

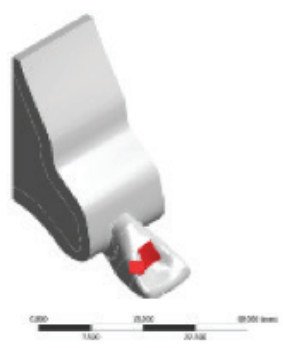

B

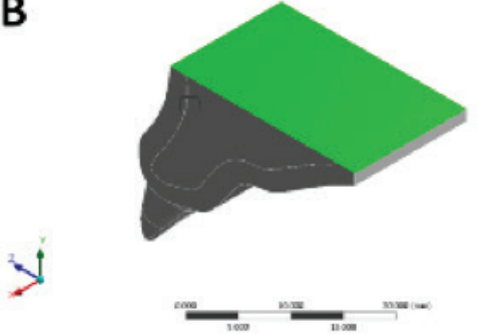

C

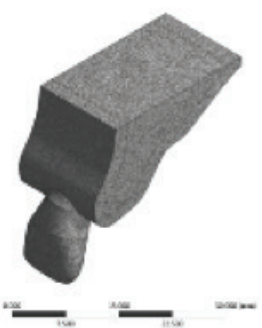

Figure 2 - (A) Image composed by arrangement of tetrahedral elements and meshes. (B) Force vector applied in the static analysis test. (C) Fixing system.

A
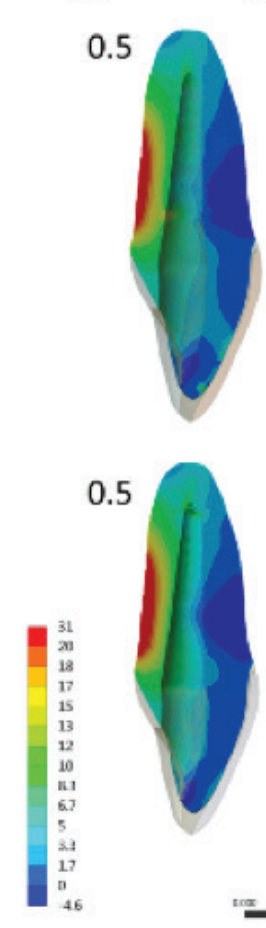

Models without GFP

0.7

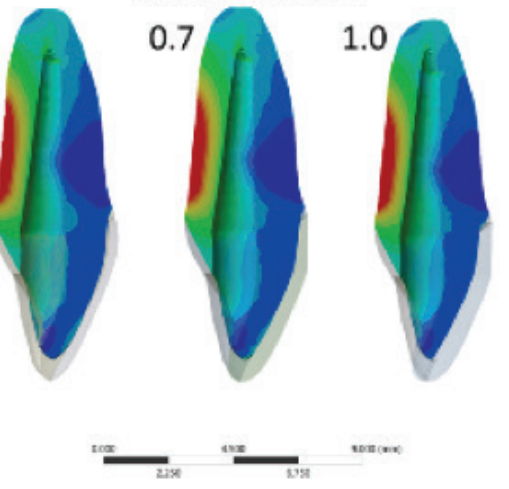

B Models without GFP

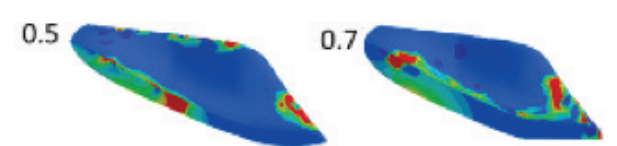

Models with GFP



C

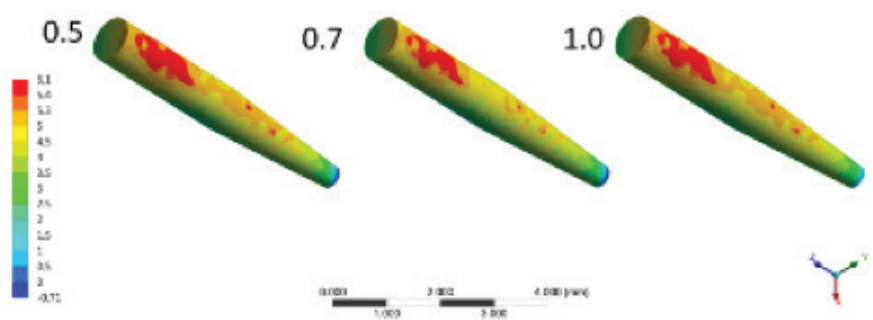

Figure 3 - Maximum principle stresses results at models with different veneer thickness (0.5, 0.7 and 1.0) and with or without GFP. (A) Stress distribution at dentin. (B) Stress distributions at veneer (sectioned). (C) Stress distribution at fiber post.

\section{DISCUSSION}

After analysis of results and answering the objectives of this study, it was observed that despite GFP did not provide changes on the biomechanical behavior of tooth remaining external surface (qualitatively and quantitatively), this modification was found on dentin inner portion. Regarding veneer thickness, different preparation depth presented changes in stress distribution.
The FEA is a methodology that enables to analyze the biomechanical behavior of complex structures submitted to determined load. The analyzed models in this study were designed under tridimensional structures. It leads a better understanding of teeth and restorative materials mechanical properties as they are presented on the oral environment $[17,18]$. This fact can help to improve tooth preparation design and to choose appropriate restorative materials [27]. Besides that, different of 
mechanical analysis in bench studies, the structures can be standardized, reducing risk of bias that interferes with final results [11].

However, only FEA cannot be an indicator of fractures or restoration fails; it can show which restoration or tooth areas are more susceptible to failure. Stress concentration areas and their propagation can be identified on models, where fails and fractures are originated [28]. This methodology is ideally used for static analysis and to obtain some data that cannot be obtained by other laboratory methods and it is used to design better following clinical and laboratory researchers [29].

Few studies evaluated intra-radicular posts to reinforce tooth structure; their use is related to tooth damage and the restoration to be done $[30,31,32]$. The fracture risk of endodontically treated teeth depends on tooth structure loss, cavity access, instrumentation and canal irrigation [31]. Restoration success depends on ferule conditions and extension and GFP use $[9,11]$. Some studies show anterior teeth are more susceptible to fracture [10].

GFP use has done more often because it shows better performance than conventional metallic post. GFP presents better aesthetical properties and better adhesion to resin cement [1]. A study evaluated stress distribution on endodontically treated tooth with GFP or with a dentin post. Results showed that dentin post was advantageous absorbing stress and distributing to tooth structure [15]. If the restorative material modulus of elasticity is similar to tooth's modulus of elasticity, there is less stress concentration in other areas of the tooth. This information can be found in previous studies $[13,16]$.

Comparing GFP with other post materials, GFP presents better mechanical performance. The stress distribution decreases in middle and cervical thirds in GFP about zirconia and titanium posts [14]. Tooth roots are more vulnerable to fracture as the higher the post stiffness is, and the higher the load is transferred to them [11]. Metallic posts do not properly distribute the stress received by teeth [10].

The present study showed that stress decreased in direct veneer in the group with GFP, compared to the group without GFP. GFP was able to absorb and distributes stress to teeth, protecting it from fails. It can absorb better the stress load and decrease the flexural force that enamel and dentin are submitted. This force that is not well absorbed and it is transferred to dentin and enamel, can be also transferred to veneer. Then, the veneer was weakened when GFP was not present.

Enamel has a modulus of elasticity higher than dentin, making it resisting better to deformations, absorbing stress, and do not transmit to veneer. Dentin has a lower modulus of elasticity and transmits more stress to adjacent structures, such as composite resin. The insufficient tooth reduction can be injurious to restoration resistance. However, higher tooth reduction is injurious because the veneers are bonded mostly in dentin, while lower thickness can damage mechanic behavior of composite resin [7]. To obtain better adhesion conditions, $50-70 \%$ of tooth substrate should be enamel. The restoration longevity decreases if adhered in its most part in dentin [3]. Adhesion has an essential role in direct veneers performance because they do not have macromechanical retention due to preparation design [6]. Models with $1.0 \mathrm{~mm}$ thickness veneers did not show good biomechanical behavior on stress distribution. It can be worse with the fact that veneer is bonded in their most extension to dentin substrate. The $0.5 \mathrm{~mm}$ thickness veneer had the worst results on stress distribution because they do not have a material thickness enough to absorb applied forces, making its inner structure less resistance [7].

\section{CONCLUSION}

Within limitations of this study, it can be concluded that GFP use is biomechanically favorable for restored teeth with direct veneers. Regarding veneer thickness, very thin 
or very thick preparations can damage the biomechanical behavior of restorations.

\section{REFERENCES}

1. Korkut B, Yanikoglu F, Gunday M. Direct composite laminate veneers: three case reports. Journal of dental research, dental clinics, dental prospects. 2013;7(2):105-11. doi: 10.5681/joddd.2013.019.

2. Pini NP, Aguiar FH, Lima DA, Lovadino JR, Terada RS, Pascotto RC Advances in dental veneers: materials, applications, and techniques. Clinical, cosmetic and investigational dentistry. 2012;4:9-16. doi: 10.2147/ cciden.s7837.

3. Gresnigt MM, Kalk W, Ozcan M. Randomized controlled split-mouth clinical trial of direct laminate veneers with two micro-hybrid resin composites. Journal of dentistry. 2012 Sep;40(9):766-75. doi: 10.1016/j.jdent.2012.05.010.

4. Matson MR, Lewgoy HR, Barros Filho DA, Amore R, Anido-Anido A, Alonso RC, et al. Finite element analysis of stress distribution in intact and porcelain veneer restored teeth. Computer methods in biomechanics and biomedical engineering. 2012;15(8):795-800. doi: 10.1080/10255842.2011.561013.

5. Akoglu B, Gemalmaz D. Fracture resistance of ceramic veneers with different preparation designs. Journal of prosthodontics : official journal of the American College of Prosthodontists. 2011 Jul;20(5):380-4. doi: 10.1111/j.1532-849X.2011.00728.x.

6. Layton DM, Clarke M, Walton TR. A systematic review and meta-analysis of the survival of feldspathic porcelain veneers over 5 and 10 years. The International journal of prosthodontics. 2012 Nov-Dec;25(6):590-603.

7. Ausiello P,Franciosa P, Martorelli M, Watts DC. Mechanical behavior of post-restored upper canine teeth: a 3D FE analysis. Dental materials : official publication of the Academy of Dental Materials. 2011 Dec;27(12):1285-94. doi: 10.1016/j.dental.2011.09.009.

8. Dal Piva AMd0, Tribst JPM, e Souza ROdA, Borges ALS. Influence of Alveolar Bone Loss and Cement Layer Thickness on the Biomechanical Behavior of Endodontically Treated Maxillary Incisors: A 3-dimensional Finite Element Analysis. Journal of Endodontics. 2017.

9. Al-Omiri MK, Mahmoud AA, Rayyan MR, Abu-Hammad O. Fracture resistance of teeth restored with post-retained restorations: an overview. J Endod. 2010 Sep;36(9):1439-49. doi: 10.1016/j.joen.2010.06.005.

10. Dietschi D, Duc 0, Krejci I, Sadan A. Biomechanical considerations for the restoration of endodontically treated teeth: a systematic review of the literature--Part 1. Composition and micro- and macrostructure alterations. Quintessence international (Berlin, Germany : 1985). 2007 0ct;38(9):73343.

11. Bergoli CD, Meira JB, Valandro LF, Bottino MA. Survival rate, load to fracture, and finite element analysis of incisors and canines restored with ceramic veneers having varied preparation design. Operative dentistry. 2014 Sep-0ct;39(5):530-40. doi: 10.2341/13-179.

12. Chieruzzi M, Pagano S, Cianetti S, Lombardo G, Kenny JM, Torre L. Effect of fibre posts, bone losses and fibre content on the biomechanical behaviour of endodontically treated teeth: 3D-finite element analysis. Materials science \& engineering C, Materials for biological applications. 2017 May 01;74:334-46. doi: 10.1016/.j.msec.2016.12.022.

13. Coelho-de-Souza FH, Goncalves DS, Sales MP, Erhardt MC, Correa MB, Opdam NJ, et al. Direct anterior composite veneers in vital and non-vital teeth: a retrospective clinical evaluation. Journal of dentistry. 2015 Nov;43(11):1330-6. doi: 10.1016/j.jdent.2015.08.011
14. Mosharraf R, Haerian A. Push-out bond strength of a fiber post system with two resin cements. Dental research journal. 2011 Dec;8(Suppl 1):S8893. doi.

15. Rajambigai A, Kumar A, Sabarinathan, Raja R. Comparison of Stress Distribution in a Maxillary Central Incisor Restored with Two Prefabricated Post Systems with and without Ferrule Using Finite Element Method. Journal of clinical and diagnostic research: JCDR. 2016 Sep;10(9):ZC52ZC5. doi: 10.7860/jcdr/2016/19443.8492.

16. Skupien JA, Sarkis-Onofre R, Cenci MS, Moraes RR, Pereira-Cenci T. A systematic review of factors associated with the retention of glass fiber posts. Brazilian oral research. 2015;29. doi: 10.1590/1807-3107BOR-2015. vol29.0074.

17. Soares CJ, Versluis A, Valdivia ADCM, Bicalho AA, Veríssimo C, Barreto BdCF, et al. Finite element analysis in dentistry-improving the quality of oral health care. Finite Element Analysis-From Biomedical Applications to Industrial Developments: InTech; 2012

18. Trivedi S. Finite element analysis: $A$ boon to dentistry. Journal of oral biology and craniofacial research. 2014 Sep-Dec;4(3):200-3. doi: 101016/j. jobcr.2014.11.008

19. Versluis A, Tantbirojn D, Pintado MR, DeLong R, Douglas WH. Residual shrinkage stress distributions in molars after composite restoration. Dental materials : official publication of the Academy of Dental Materials. 2004 Jul;20(6):554-64. doi: 10.1016/j.dental.2003.05.007.

20. Friedman CE, Sandrik JL, Heuer MA, Rapp GW. Composition and physical properties of gutta-percha endodontic filling materials. J Endod. 1977 Aug;3(8):304-8. doi: 10.1016/S0099-2399(77)80035-6.

21. Rosatto CM, Bicalho AA, Verissimo C, Braganca GF, Rodrigues MP, Tantbirojn D, et al. Mechanical properties, shrinkage stress, cuspal strain and fracture resistance of molars restored with bulk-fill composites and incremental filling technique. Journal of dentistry. 2015 Dec;43(12):1519-28. doi: 10.1016/j.jdent.2015.09.007.

22. Lassila LV, Tanner J, Le Bell AM, Narva K, Vallittu PK. Flexural properties of fiber reinforced root canal posts. Dental materials : official publication of the Academy of Dental Materials. 2004 Jan;20(1):29-36.

23. Lopes CdCA, Rodrigues RB, Simamoto Júnior PC, Soares CJ, Novais VR. Degree of conversion and mechanical properties of resin cements cured through different all-ceramic systems. Brazilian dental journal. 2015;26(5):484-9.

24. Rundquist $\mathrm{BD}$, Versluis $\mathrm{A}$. How does canal taper affect root stresses? International endodontic journal. 2006 Mar;39(3):226-37. doi: 10.1111/j.13652591.2006.01078.x.

25. Carter DR, Hayes WC. The compressive behavior of bone as a two-phase porous structure. The Journal of bone and joint surgery American volume. 1977 0ct;59(7):954-62.

26. Conci RA, Tomazi FH, Noritomi PY, da Silva JV, Fritscher GG, Heitz C. Comparison of Neck Screw and Conventional Fixation Techniques in Mandibular Condyle Fractures Using 3-Dimensional Finite Element Analysis. Journal of oral and maxillofacial surgery : official journal of the American Association of Oral and Maxillofacial Surgeons. 2015 Jul;73(7):1321-7. doi: 10.1016/j.joms.2015.01.037.

27. Zarone F, Apicella D, Sorrentino R, Ferro V, Aversa R, Apicella A. Influence of tooth preparation design on the stress distribution in maxillary central incisors restored by means of alumina porcelain veneers: $\mathrm{a} 3 \mathrm{D}$-finite element analysis. Dental materials : official publication of the Academy of Dental Materials. 2005 Dec;21(12):1178-88. doi: 10.1016/j.dental.2005.02.014. 
28. Furuya $Y$, Huang SH, Takeda Y, Fok A, Hayashi M. Fracture strength and stress distributions of pulpless premolars restored with fiber posts. Dental materials journal. 2014;33(6):852-8.

29. Silva NR, Castro CG, Santos-Filho PC, Silva GR, Campos RE, Soares PV, et al. Influence of different post design and composition on stress distribution in maxillary central incisor: Finite element analysis. Indian journal of dental research : official publication of Indian Society for Dental Research. 2009 Apr-Jun;20(2):153-8. doi: 10.4103/0970-9290.52888.

30. Baratieri LN, De Andrada MA, Arcari GM, Ritter AV. Influence of post placement in the fracture resistance of endodontically treated incisors veneered with direct composite. The Journal of prosthetic dentistry. 2000 Aug;84(2):180-4. doi: 10.1067/mpr.2000.108415
31. Santos-Filho PC, Verissimo C, Soares PV, Saltarelo RC, Soares CJ, Marcondes Martins LR. Influence of ferrule, post system, and length on biomechanical behavior of endodontically treated anterior teeth. J Endod. 2014 Jan;40(1):119-23. doi: 10.1016/j.joen.2013.09.034.

32. Barcellos R, Correia D, Farina A. Fracture resistance of endodontically treated teeth restored with intra-radicular post: The effects of post system and dentine thickness. J Biomech. 2013 Aug;46(15):2572-77. doi:10.1016/j. jbiomech.2013.08.016

\section{Taciana Marco Ferraz Caneppele} (Corresponding address)

Engenheiro Francisco José Longo Av, 777

Zip code: $12245-000$ 